\title{
Probiotic Psychrobacter sp. improved the autochthonous microbial diversity along the gastrointestinal tract of grouper Epinephelus coioides
}

\author{
Hong-Ling Yang ${ }^{1}$, Yun-Zhang Sun ${ }^{1,2 *}$, Ru-Long Ma ${ }^{1}$, Jiang-Sen Li $^{1}$, Kun-Peng Huang ${ }^{1}$ \\ ${ }^{1}$ The Key Laboratory of Science and Technology for Aquaculture and Food Safety of Fujian Province University, Fisheries College, Jimei University, Xiamen 361021, \\ China
}

${ }^{2}$ Xiamen Key Laboratory for Feed Quality Testing and Safety Evaluation, Fisheries College, Jimei University, Xiamen 361021, China

\begin{abstract}
The effect of dietary administration of probiotic Psychrobacter sp. SE6 for 60 days on the autochthonous microbiota in the foregut, midgut and hindgut of juvenile grouper Epinephelus coioides was assessed using polymerase chain reaction-denaturing gradient gel electrophoresis (PCR-DGGE). A complex and generally similar bacterial composition was present along the gastrointestinal $(\mathrm{Gl})$ tract of fish fed the probiotic or control diet. However, samples collected from the probiotic group and control group showed different DGGE patterns. The similarity dendrogram demonstrated that all nine samples from the control group were closely related and distinctly different to the probiotic samples. The total number of bands and Shannon index of the foregut, midgut and hindgut samples in the probiotic group were significantly higher than those in the control group, suggesting probiotic $P$ sychrobacter sp. improved the autochthonous microbial diversity along the GI tract of $E$. coioides. Some potentially beneficial and uncultured bacteria were stimulated, while some potentially harmful species, such as Staphylococcus saprophyticus, were suppressed. Sequence analysis showed that the majority of bacterial sequences $(48.0 \%)$ in this study were highly similar to unidentified clones, suggesting a considerable proportion of unknown bacteria in the gut of $E$. coioides.
\end{abstract}

Keywords: Gut microbiota; Probiotic; Psychrobacter sp; Epinephelus coioides; DGGE

\section{Introduction}

The increased intensification of aquaculture has led to a high number of disease outbreaks with an increasing range of pathogens. Traditional disease control strategies employ antibiotics and chemical disinfectants, but these are no longer recommended practices due to the emergence of bacterial resistance, and also due to concerns over environmental impacts. Therefore, the use of probiotics has been suggested to be an alternative method for the prevention and control of various diseases in aquaculture [1-3]. Recently, the potential of using probiotic Lactobacillus plantarum [4] and Bacillus sp. [5] for disease control, immune stimulation and growth promotion have been demonstrated in grouper Epinephelus spp., one of the most important mariculture fish species in China and Southeast Asian countries [4]. However, the mechanisms behind these benefits are not well understood. Recently, it is suggested that a clear understanding on the effect of probiotics on the autochthonous gut microbiota is integral to illustrate the mechanisms responsible for probiotic benefits [3].

The gastrointestinal (GI) tract of fish harbours a complex microbial community, including two distinct groups, i.e. allochthonous (exogenous) and autochthonous (indigenous) [1]. Autochthonous organisms are reported to play important roles within the GI tract, including the capacity to contribute to the development/maturation of the gut and immune system $[1,6,7]$, and provide resistance to infectious pathogens $[8,9]$. The autochthonous microbiota has also been reported to inhibit the colonization of introduced bacteria by mechanisms including space occupation, competition for substances and receptors at mucosal surfaces, and secretion of inhibitory substance [2]. However, little information is available on the impact of probiotics administration on the gut autochthonous microbiota of fish [2,3]. Moreover, previous gut microbial studies often have used cultivation-based techniques, which obviously only allow the investigation of culturable bacteria, while the effect on non-culturable bacteria, which may account for the majority of the bacterial population in the gut of fish, remained largely unclear $[2,3,10]$. As an alternative, genetic fingerprint methods based on polymerase chain reaction (PCR) amplification of $16 \mathrm{~S}$ rRNA gene and denaturing gradient gel electrophoresis (DGGE) have been successfully applied in gut microbiota study [3,10-15].

Recently, we compared the gut microbiota of fast and slow growing grouper Epinephelus coioides. The results showed that Psychrobacter sp. SE6 dominated in the gut of fast growing fish, but was absent in the gut of slow growing fish [16]. In vitro study showed that this strain exhibited antagonistic activity against several fish pathogens [16]. Subsequently, a 60 days of feeding trial confirmed that it could improve the feed utilization and immune responses of juvenile grouper E. coioides [17] In the present study, PCR-DGGE with subsequent sequence analysis was used to assess the effect of dietary administration of probiotic Psychrobacter sp. SE6 on the autochthonous microbiota along the GI tract of grouper E. coioides.

\section{Materials and Methods}

\section{Bacterial strain}

Psychrobacter sp. SE6 was isolated from the whole intestine of juvenile grouper E. coioides and identified based on physiological and biochemical tests, such as cell shape, pigmentation, Gram stain, catalase test, utilization of Simmon Citrate, sugar fermentation and so on, and this strain was characterized further by $16 \mathrm{~S}$ rRNA gene sequencing

*Corresponding author: Dr. Yun-Zhang Sun,Fisheries College, Jimei University Yindou road No. 43, Jimei District, Xiamen, 361021, China,Tel: 00865926181420 Fax: 0086592 6181847; E-mail: sunyunzhang@yahoo.com.cn

Received June 28, 2011; Accepted August 15, 2011; Published September 10 2011

Citation: Yang HL, Sun YZ, Ma RL, Li JS, Huang KP (2011) Probiotic Psychrobacter sp. improved the autochthonous microbial diversity along the gastrointestinal tract of grouper Epinephelus coioides. J Aquac Res Development S1:001. doi:10.4172/2155-9546.S1-001

Copyright: ( 2011 Yang HL, et al. This is an open-access article distributed unde the terms of the Creative Commons Attribution License, which permits unrestricted use, distribution, and reproduction in any medium, provided the original author and source are credited. 
Citation: Yang HL, Sun YZ, Ma RL, Li JS, Huang KP (2011) Probiotic Psychrobacter sp. improved the autochthonous microbial diversity along the gastrointestinal tract of grouper Epinephelus coioides. J Aquac Res Development S1:001. doi:10.4172/2155-9546.S1-001

Page 2 of 6

(GenBank accession number: EU520334) [16]. The strain was cultured and prepared as described previously [16]. Briefly, $50 \mu \mathrm{l}$ of Psychrobacter sp. storage solution was inoculated in $20 \mathrm{ml}$ nutrient broth. After 24 $h$ of incubation, the cells were harvested and re-suspended in PBS for addition to the basal diet. The number of bacteria in the suspension was $1.0 \times 10^{10}$ cells $\mathrm{ml}^{-1}$, which was determined by plate counting on tryptone soya agar (TSA) at $28^{\circ} \mathrm{C}$ for $48 \mathrm{~h}$.

\section{Diet preparation and feeding trial}

The control diet was formulated using the ingredients as showed in Table 1 . The probiotic diet was prepared by gently spraying the required amount of bacterial suspension on the control diet $(10 \mathrm{ml}$ bacterial suspension per $\mathrm{kg}$ diet) and mixing it part-by-part in a three dimensions drum mixer (SYH-100, Punaier Drying Equipment Co., Ltd, Changzhou, China) to obtain a final probiont concentration of $1.0 \times 10^{8}$ cells $\mathrm{g}^{-1}$. Dietary ingredients of the respective probiotic and control diets were mixed with required amount of water and then cold press extruded (CD4XITS extruder, South China University of Technology, Guangzhou, China) to produce $5 \mathrm{~mm}$ pellets, which were dried for 3 days at room temperature $\left(20-25^{\circ} \mathrm{C}\right)$ and packed in sterile polypropylene containers and stored at $4^{\circ} \mathrm{C}$. The counts of probiotic Psychrobacter sp. in the diets were determined by spread plating on TSA as described by [17].

Juvenile grouper E. coioides were obtained from a local commercial farm and transported to the Aquaculture Research Aquarium, University of Jimei, China. Fish were fed the control diet and acclimated for 4 weeks before the beginning of the trial. The feeding experiment was conducted in six 180-1 seawater fibreglass tanks, each connected to an open circulating system $\left(35 \mathrm{~g} \mathrm{l}^{-1}\right.$ salinity, at $\left.28 \pm 2^{\circ} \mathrm{C}\right)$. Each tank was randomly stocked with 14 fish $(45.02 \pm 0.18 \mathrm{~g})$ and each treatment was conducted in triplicate. Fish were fed the control diet or probiotic diet. The fed level was $3 \%$ biomass per day provided in equal rations at 09:00 and 17:00 $\mathrm{h}$ for 60 days.

At the end of the trial (day 60), three individual fish from each treatment were randomly collected and the GI tract of each fish was sampled and divided into foregut, midgut and hindgut as previously described [18]. The foregut refers to the stomach, the midgut includes the pyloric caeca and proximal intestine as fish pyloric caeca has similar functions as proximal intestine [19], and the hindgut refers to distal portion of the intestine. Each section was aseptically excised and the digesta was removed as described in [20]. Each GI section was homogenized using a glass homogenizer and stored at $-80{ }^{\circ} \mathrm{C}$ until further analysis. In the present study, three individual fish in each group (fish C1, C2 and C3 in the control group, fish P1, P2 and

\begin{tabular}{lcc}
\hline Ingredients & Control & Probiotic \\
\hline Fish meal & 600 & 600 \\
Soybean meal & 160 & 160 \\
Shrimp meal & 20 & 20 \\
Wheat flour & 140 & 140 \\
Fish oil & 40 & 40 \\
Soybean phospholipids & 20 & 20 \\
Vitamin mixture $^{*}$ & 10 & 10 \\
Mineral mixture $^{\dagger}$ & 10 & 10 \\
Psychrobacter sp. $^{*}$ & 0 & $1.0 \times 10^{8}$
\end{tabular}

*Vitamin and ${ }^{\dagger}$ mineral mixture for Epinephelus coioides provided by Haikang Feed Company, Zhaoan, Zhangzhou, China.

Table 1: Composition of the basal diet $\left(\mathrm{g} \mathrm{kg}^{-1}\right)$ and probiotic level (cells $\mathrm{g}^{-1}$ ) for Epinephelus coioides.
P3 in the probiotic group) were investigated as previous studies have demonstrated inter-fish variation in the gut microbiota [20,21].

\section{DNA extraction, PCR amplification and DGGE analysis}

Total DNA was extracted from the homogenates of GI sections as described by [22]. Primers 338f (5'-ACTCCTACGGGAGGCAGCAG-3' with a GC clamp CGCCCGGGGCGCGCCCCGGGCGGGGCGGGGGCACGGGGGG at the 5' end) and 519r (5'-ATTACCGCGGCTGCTGG-3') were used to amplify the V3 region of the bacterial $16 \mathrm{~S}$ rRNA gene [23]. A touchdown PCR [12] was performed for all samples to reduce nonspecific priming by using a MJ Mini thermocycler (Bio-Rad, Hercules, California, USA).

PCR products of the V3 region of 16S rRNA gene from the gut samples were used for sequence-specific separation by DGGE [22], using a Dcode TM system (Bio-Rad, Hercules, CA, USA). DGGE was performed in $8 \%$ polyacrylamide gels containing 37.5:1 acrylamidebiacrylamide and a denaturing gradient of $35-50 \%$ of urea and formamide. All PCR products ( $10 \mu \mathrm{l}$ for each sample) were loaded on the same gel. The electrophoresis was initiated by pre-running for 10 min at $200 \mathrm{~V}$, and subsequently ran at a fixed voltage of $85 \mathrm{~V}$ for 12 $\mathrm{h}$ at $60^{\circ} \mathrm{C}$. After completion of electrophoresis, the gel was stained in $0.2 \% \mathrm{AgNO}_{3}$ solution for $10 \mathrm{~min}$ and then visualized in a visualization solution (trace $\mathrm{NaBH} 4$ in $1.5 \% \mathrm{NaOH}$ ), and scanned using GS 800 Calibrated Densitometer (Bio-Rad, Hercules, CA, USA).

\section{Analysis of DGGE patterns}

DGGE patterns were analyzed as described in [22] using software of GelCompar ${ }^{\circledR}$ (Applied Maths, Austin, TX, USA). Levels of similarity between fingerprints were calculated according to the Dice similarity coefficient $\left(S_{D}\right)$ as previously described [24]. The unweighted pair group method with arithmetic averages (UPGMA) was used to create a dendrogram representing the similarity of the microbial profiles from the DGGE fingerprints [22]. In order to determine the structural diversity of the microbial community corresponding to the DGGE banding pattern, two indices were calculated: (1) the species richness (R) was calculated based on the total number of bands. (2) the Shannon index $\left(H^{\prime}\right)$ which reflects the diversity of the whole microbial community. These data were analyzed by one-way of analysis of variance (ANOVA) followed by Duncan's multiple comparison procedure using the statistical packages for the Social Sciences (SPSS), release 14.0 (SPSS, Inc., Chicago, IL). Significant differences were declared at $P \leq 0.05$.

\section{Sequencing of DGGE bands}

Bands of interest were excised for sequence analysis as previously described [22]. Briefly, DNA was eluted from excised bands in $50 \mu \mathrm{l}$ TE buffer (10 mM Tris-HCl, $1 \mathrm{mM}$ EDTA, $\mathrm{pH}$ 8.0) at $4{ }^{\circ} \mathrm{C}$ overnight. PCR was performed using $2 \mu \mathrm{l}$ of the elution as template to amplify the V3 region of 16S rRNA gene with primers 338f and 519r [23]. The PCR products were cleaned using the QIAquick PCR Purification Kit (QIAGEN, Valencia, CA, USA) and sequenced by Invitrogen Biotechnology Co., Ltd (Shanghai, China). The sequences were checked for chimeric constructs by using the CHECK CHIMERA program of the ribosomal database project (RDP) [25]. The resulting sequences ( $200 \mathrm{bp}$ ) were compared with the sequences from the National Center for Biotechnology Information (NCBI) using the BLAST sequence algorithm to retrieve the closest known alignment identities. The sequences reported in this study have been deposited in the GenBank database under the following accession numbers: lcl951, lcl9953, lcl16591, lcl17197, lcl22649, lcl25487, lcl25609, lcl28133, lcl28577, lcl28947, lcl29719, lcl31463, lcl34599, lcl36143, lcl38265, lcl43263, 
Citation: Yang HL, Sun YZ, Ma RL, Li JS, Huang KP (2011) Probiotic Psychrobacter sp. improved the autochthonous microbial diversity along the gastrointestinal tract of grouper Epinephelus coioides. J Aquac Res Development S1:001. doi:10.4172/2155-9546.S1-001

Page 3 of 6

lcl44189, lcl52867, lcl54423, lcl54911, lc155019, lcl56485, lcl58261, lcl58447 and lcl63159.

\section{Results}

\section{Gut microbiota analysis by DGGE}

The PCR-DGGE techniques were employed to evaluate the autochthonous bacterial diversity of the foregut, midgut and hindgut samples from fish fed the probiotic diet and control diet (Figure 1). In general, samples collected from probiotic group had similar DGGE patterns, with 20 to 26 bands to each sample, while samples collected from the control group also showed similar DGGE patterns, with 14 to 19 bands to each sample (Figure 1). This suggested that the bacterial community was generally similar among the three GI sections of fish fed the probiotic diet or control diet (Figure 2), and the probiotic diet might increased the bacterial diversity along the GI tract of E. coioides.

The similarty dendrogram showed that all nine samples from the control group were closely related, with a high similarity index (62.5\%), which was distinctly different to the probiotic samples (Figure 2). The relatively low similarities between the probiotic and control samples in the similarity dendrogram confirmed the visual differences in DGGE profiles. The total number of bands (R) and the Shannon index $\left(H^{\prime}\right)$ of the foregut, midgut and hindgut samples in the probiotic group were significantly higher than those in the control group (Figure 3a, $3 \mathrm{~b})$, which further confirmed that the probiotic diet increased the autochthonous microbial diversity along the GI tract of E. coioides.

\section{Sequences from bands in DGGE gel}

A total of 27 bands (band 1-27) were excised from the DGGE gel, and 25 bands were successfully sequenced (Figure 1) and the BLAST results were present in Table 2 . The 25 identified bacteria were closely

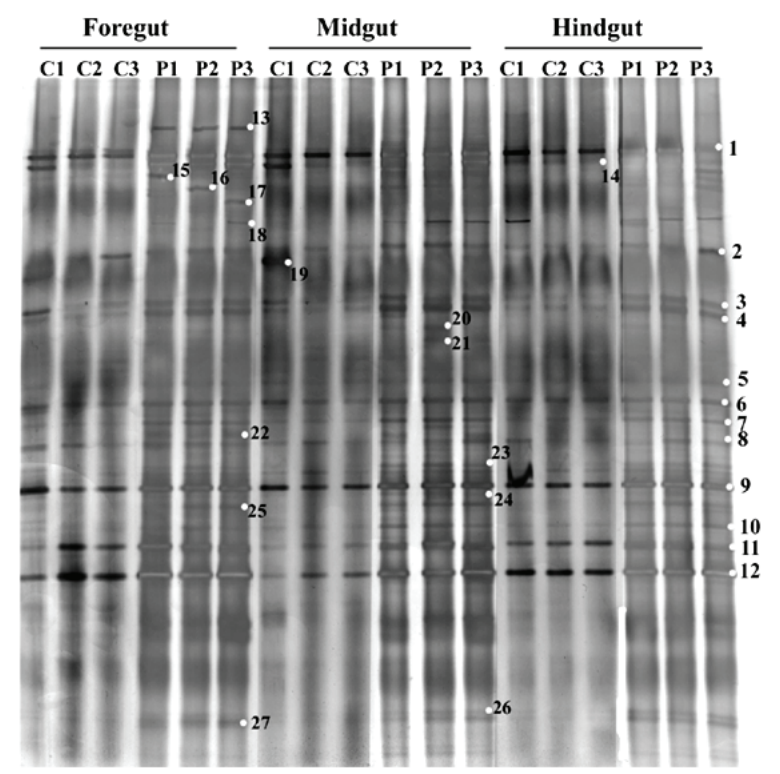

Figure 1: DGGE profiles of the foregut, midgut and hindgut samples in Epinephelus coioides fed the control diet and probiotic diet for 60 days. C1, C2 and C3 represent the three fish fed the control diet, while P1, P2 and P3 represent the three fish fed the probiotic diet. Band 1-12 are common bands to all samples, band 14 and 19 are present only in the control group, while band $13,15-18,20-27$ only in the probiotic group. Those bands are sequenced and described in Table 2.

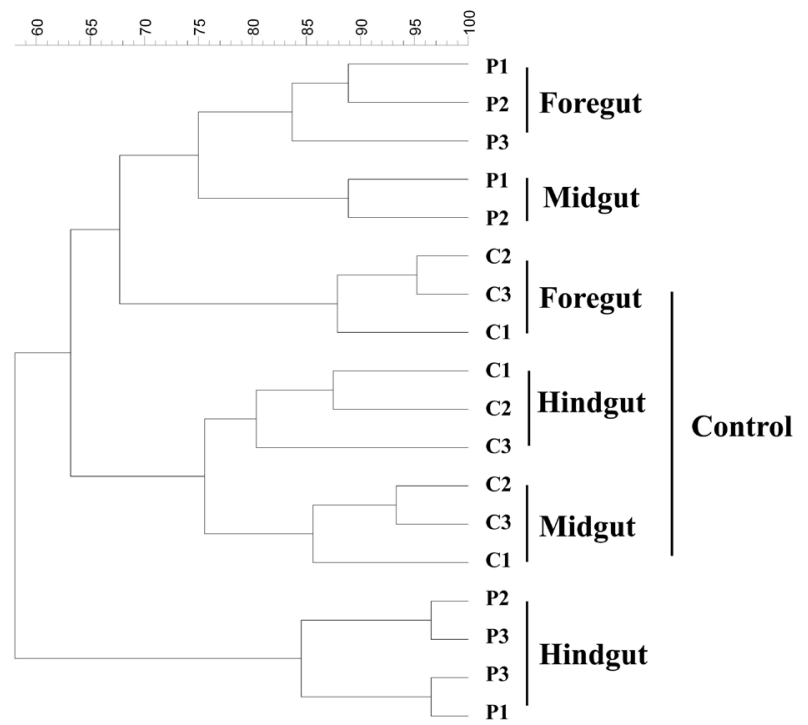

Figure 2: Unweighted pair group clustering dendrogram of DGGE profiles using arithmetic average linkage. C1, C2 and C3 represent the three fish fed the control diet, while P1, P2 and P3 represent the three fish fed the probiotic diet.
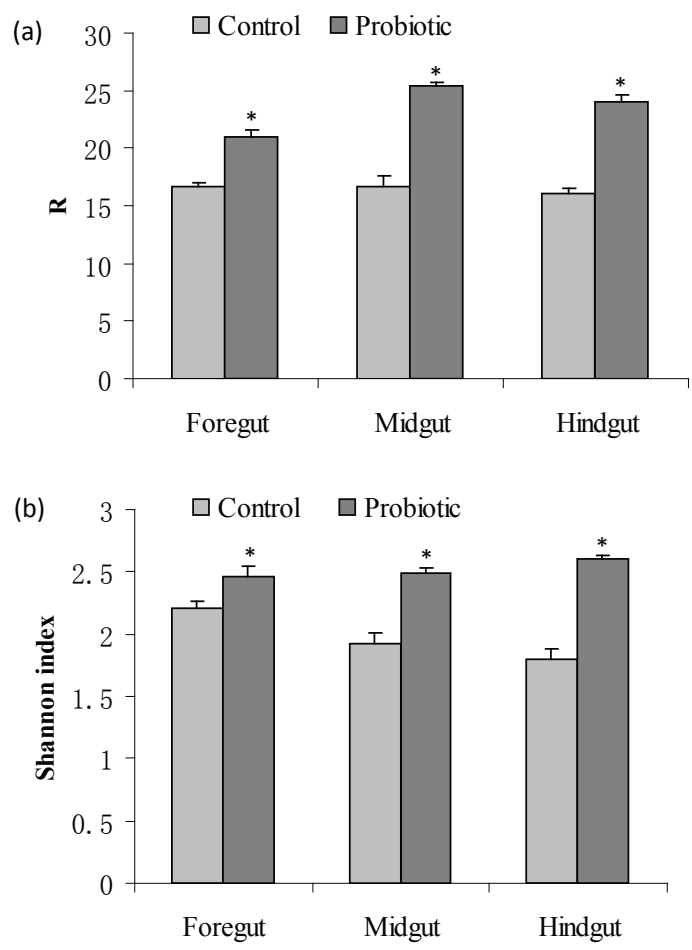

Figure 3: Analysis of DGGE banding patterns from samples of the foregut, midgut and hindgut in Epinephelus coioides fed the control diet and probiotic diet for 60 days. a. Number of DGGE bands $(R)$. b. Shannon index $\left(H^{\prime}\right)$. *significant difference between the fish fed the probiotic diet and control diet $(P \leq 0.05)$

related to one of the following four groups: Proteobacteria $(32.0 \%$ of the total), Actinobacteria (12.0\%), Firmicutes (8.0\%) and unclassified bacteria (48.0\%). Twelve common bacteria (corresponding to band 1-12) were present in all samples, including Pseudomonas sp. CB10-like, 
Citation: Yang HL, Sun YZ, Ma RL, Li JS, Huang KP (2011) Probiotic Psychrobacter sp. improved the autochthonous microbial diversity along the gastrointestinal tract of grouper Epinephelus coioides. J Aquac Res Development S1:001. doi:10.4172/2155-9546.S1-001

Page 4 of 6

Nitratireductor sp. YCSC5-like, Methylobacterium hispanicum strainlike, Microbacterium sp. YACS1-like, Dietzia sp. N11-like bacterium and seven uncultured bacterium clone-like bacteria.

Twelve bands (band 13,15-17 and 20-27) were present only in the probiotic group (Figure 1). Band 13, 15-17 and 22 were observed only in the foregut, band 13 and 22 observed in three fish and showed $94 \%$ and $99 \%$ similarity to Micrococcus luteus and uncultured beta proteobacterium isolate DGGE gel band YL6, respectively, while band 15,16 and 17 observed in one fish (fish P1, P2 and P3, respectively) and were most closely related to uncultured bacterium. Band 20 and 21 were present in the midgut and most closely related to Alcanivorax dieselolei strain Qtet3 and uncultured alpha proteobacterium clone A22YB05RM, respectively. Band 23-27 were observed in all the probiotic samples, band 23, 24 and 25 were most closely related to uncultured bacterium.

On the contrary, band 19 appeared only in midgut of fish $\mathrm{C} 1$ fed the control diet and showed $98 \%$ similarity to Bacillus sp. JZDN5. Band 14 presented in all the probiotic samples, but missed in the hindgut samples of the control group and showed $99 \%$ similarity to Staphylococcus saprophyticus.

\section{Discussion}

The effect of dietary administration of probiotic Psychrobacter sp. SE6 on the autochthonous microbiota along the GI tract of $E$. coioides was evaluated for the first time using PCR-DGGE with subsequent sequencing analysis. Our data demonstrated that probiotic Psychrobacter sp. significantly increased the autochthonous microbial diversity (visible band number and Shannon diversity index) of $E$. coioides. In line with our finding, dietary administration of fresh or lyophilized probiotic Shewanella putrefaciens Pdp11 for 60 days exerted an important influence on intestinal bacterial DGGE profiles and yielded a faster stabilization of the bacterial community in flat fish Solea senegalensis [14]. On the contrary, dietary supplementation with Pediococcus acidilactici for 32 days significantly reduced the microbial diversity and richness in the intestine of red tilapia (Oreochromis niloticus) [26]. Therefore, different probiotic strains may exert different effect on the gut microbiota of fish. However, direct comparisons between these studies are also difficult because these strains are functionally different and the results may be affected by genetic, nutritional and environmental factors.

\begin{tabular}{|c|c|c|c|c|}
\hline Phylogenic group & Band no. & Closest relative & Similarity (\%) & Accession no. \\
\hline \multirow[t]{8}{*}{ Proteobacteria } & 1 & Pseudomonas sp. CB10 & $99 \%$ & Icl29719 \\
\hline & 9 & Nitratireductor sp. YCSC5 & $100 \%$ & Ic|22649 \\
\hline & 10 & $\begin{array}{l}\text { Methylobacterium hispanicum } \\
\text { strain }\end{array}$ & $94 \%$ & Icl28133 \\
\hline & 18 & $\begin{array}{l}\text { Uncultured alpha proteobac- } \\
\text { terium }\end{array}$ & $94 \%$ & Icl38265 \\
\hline & 20 & $\begin{array}{l}\text { Uncultured alpha proteobacte- } \\
\text { rium clone A22YB05RM }\end{array}$ & $92 \%$ & Icl31463 \\
\hline & 21 & $\begin{array}{l}\text { Alcanivorax dieselolei strain } \\
\text { Qtet3 }\end{array}$ & $88 \%$ & Ic|25609 \\
\hline & 22 & $\begin{array}{l}\text { Uncultured beta proteobacterium } \\
\text { isolate DGGE gel band YL6 }\end{array}$ & $96 \%$ & Ic154423 \\
\hline & 23 & $\begin{array}{l}\text { Uncultured alpha proteobac- } \\
\text { terium }\end{array}$ & $100 \%$ & Icl58447 \\
\hline \multirow[t]{2}{*}{ Firmicutes } & 14 & Staphylococcus saprophyticus & $99 \%$ & Icl25487 \\
\hline & 19 & Bacillus sp. JZDN5 & $98 \%$ & Ic|28577 \\
\hline \multirow[t]{3}{*}{ Actinobacteria } & 11 & Microbacterium sp. YACS1 & $99 \%$ & Ic|58261 \\
\hline & 12 & Dietzia sp. N11 & $98 \%$ & Icl16591 \\
\hline & 13 & Micrococcus luteus & $94 \%$ & Icl63159 \\
\hline \multirow[t]{12}{*}{ Unclassified bacteria } & 2 & $\begin{array}{l}\text { Uncultured bacterium clone } \\
\text { HKTUI136 }\end{array}$ & $98 \%$ & Ic|54911 \\
\hline & 3 & $\begin{array}{l}\text { Uncultured bacterium clone } \\
\text { FATNRJA N079 }\end{array}$ & $99 \%$ & Icl43263 \\
\hline & 4 & $\begin{array}{l}\text { Uncultured bacterium clone } \\
16 \text { saw } 7707\end{array}$ & $98 \%$ & Icl951 \\
\hline & 5 & $\begin{array}{l}\text { Uncultured bacterium partial 16S } \\
\text { rRNA gene, clone 9-C02 }\end{array}$ & $97 \%$ & Icl44189 \\
\hline & 6 & $\begin{array}{l}\text { Uncultured bacterium clone } \\
\text { CX-1 }\end{array}$ & $99 \%$ & Icl28947 \\
\hline & 7 & $\begin{array}{l}\text { Uncultured bacterium clone } \\
\text { D3T-094 }\end{array}$ & $95 \%$ & Icl56485 \\
\hline & 8 & $\begin{array}{l}\text { Uncultured bacterium clone } \\
\text { S2-8B }\end{array}$ & $99 \%$ & Icl52867 \\
\hline & 15 & $\begin{array}{l}\text { Uncultured bacterium isolate } \\
\text { DGGE band } 34\end{array}$ & $94 \%$ & Icl55019 \\
\hline & 16 & $\begin{array}{l}\text { Uncultured bacterium clone } \\
\text { pl14H11 }\end{array}$ & $95 \%$ & Icl36143 \\
\hline & 17 & $\begin{array}{l}\text { Uncultured bacterium clone } \\
\text { STSAO- B8 }\end{array}$ & $86 \%$ & Icl34599 \\
\hline & 24 & $\begin{array}{l}\text { Uncultured bacterium isolate } \\
\text { DGGE gel band L4B5 }\end{array}$ & $100 \%$ & Ic|9953 \\
\hline & 25 & Uncultured bacterium clone C61 & $96 \%$ & Icl17197 \\
\hline
\end{tabular}

Table 2: Summary of BLAST search data arising from the bands in the DGGE gel (Figure 1) of gastrointestinal samples in Epinephelus coioides fed the probiotic diet and control diet for 60 days. 
Citation: Yang HL, Sun YZ, Ma RL, Li JS, Huang KP (2011) Probiotic Psychrobacter sp. improved the autochthonous microbial diversity along the gastrointestinal tract of grouper Epinephelus coioides. J Aquac Res Development S1:001. doi:10.4172/2155-9546.S1-001

In this study, probiotic Psychrobacter sp. improved the autochthonous microbial diversity by stimulating the growth of many bacteria, including a Micrococcus luteus-like bacterium, an Alcanivorax dieselolei-like bacterium and several uncultured bacteria. Micrococcus spp. has been isolated from the GI tract of several coastal fish [27] and gonads of Nile tilapia O. niloticus [28]. Dietary administration of $M$. luteus improved the growth and health of O. niloticus [28]. Furthermore, $M$. luteus is currently marketed as probiotics for aquaculture in India (Prowins Biotech Private Ltd., India). Therefore, we speculated that this stimulation of M. luteus-like bacterium by probiotic Psychrobacter sp. may be beneficial to the host. Another stimulated bacterium, $A$. dieselolei-like bacterium, is belonging to $\gamma$-Proteobacteria, has been isolated from sea water and deep-sea sediment [29-30]. Nakano et al. [30] found that $A$. dieselolei N1203 derived from marine sediments is a novel type of denitrifying bacterium. To our knowledge, however, $A$. dieselolei-like bacterium in the gut of fish has been identified for the first time in the present study, and its role in the gut is not clear and further study is needed.

On the other hand, probiotic Psychrobacter sp. depressed Staphylococcus saprophyticus-like bacterium to an undetectable level in the hindgut of $E$. coioides. Although there are no reports that $S$. saprophyticus caused diseases in fish, we speculate that $S$. saprophyticus may be a potentially harmful bacterium as this strain has been implicated in human urinary tract infections [31] and members of the genus Staphylococcus have been suggested as pathogens for marine and freshwater fish [32,33]. Therefore, probiotic Psychrobacter sp. seemed to exert a competitive effect on potentially pathogenic bacteria in the GI tract of E. coioides. Indeed, as one of the most dominant bacteria in the gut of E. coioides, Psychrobacter sp. has previously showed an in vitro antagonistic effect to a number of pathogenic species, such as S. aureus, Vibrio harveyi, Vibrio metschnikovi and Vibrio alginolyticus [16]. It is not surprising that dietary administration of Psychrobacter sp. SE6 inhibited the growth of some pathogenic bacteria and therefore benefited the growth of many potentially beneficial or neutral bacteria in the gut. Consequently, the gut microbial diversity increased following the administration of probiotic Psychrobacter sp. and this may be beneficial to the growth and health of E. coioides [17].

Culture-based studies have demonstrated that different autochthonous microbial communities were present in different gut sections of fish, like Atlantic salmon S. salar L. [34] and Atlantic cod Gadus morhua L. [20]. However, similar DGGE patterns were observed in the anterior mucosa (AM) and the posterior mucosa (PM) samples of rainbow trout O. mykiss (Walbaum) [35], and similar bacterial composition in the stomach, pyloric caeca and intestine of juvenile Atlantic salmon S. salar $\mathrm{L}$. was demonstrated by using different fingerprinting techniques such as temporal temperature gradient gel electrophoresis (TTGE) and restriction fragment length polymorphism (RFLP) [13]. In line with those previous molecular findings, a generally similar bacterial composition along the digestive tract was observed in E. coioides fed the probiotic diet or control diet in this study and our previous study [36]. On the contrary, Zhou et al. [10] observed different bacterial composition in the stomach, pyloric caeca and intestine of grouper E. awoara using PCR-DGGE technique. Therefore, the microbiota along the digestive tract of fish need further study.

Previous DGGE studies have demonstrated that high levels of unknown species are present in the gut of fish, such as rainbow trout O. mykiss (Walbaum) [12], hybrid tilapia (O. niloticus $q \times$ O. aureus 3) [21], grouper E. awoara [10] and flat fish S. senegalensis [14]. In line with those previous studies, the majority of bacterial sequences $(48.0 \%)$ in this study were highly similar to unidentified clones, suggesting a considerable proportion of unknown bacteria in the gut of E. coioides. A possible reason is that such organisms are fastidious and difficult to culture, and are thus not well documented. Therefore, it is suggested that culture-independent approaches may lead to the discovery of novel or unidentified bacteria and the gut microbiota of fish are not as simple as earlier believed [10]. Future probiotic studies should pay more attention to the gut microbiota of fish and evaluate it by molecular techniques, such as PCR-DGGE, quantitative real-time PCR, ribosomal intergenic spacer analysis (RISA) and RFLP. These findings will broaden our understanding of the probiotic effects at the gut level, which is integral to understand the mechanisms which underpin host benefits.

In summary, dietary supplementation of probiotic Psychrobacter sp. SE6 improved the indigenous microbial diversity along the GI tract of $E$. coioides by depressing some potentially harmful species and stimulating some potentially beneficial and uncultured bacteria.

\section{Acknowledgments}

This work was supported by National Natural Science Foundation of China (Grant No. 30600461), the Science and Technology Project for Outstanding Young Scholarship of Fujian Provincial Department of Education (Grant No. JA10183) and the Foundation of Key Laboratory of Science and Technology for Aquaculture and Food Safety of Fujian Province University (Grant No. 2009J102).

\section{References}

1. Nayak SK (2010) Probiotics and immunity: A fish perspective. Fish Shellfish Immunol 29: 2-14.

2. Nayak SK (2010) Role of gastrointestinal microbiota in fish. Aquacult Res 41 1553-1573.

3. Merrifield DL, Dimitroglou A, Foey A, Davies SJ, Baker RTM, et al. (2010) The current status and future focus of probiotic and prebiotic applications for salmonids. Aquaculture 302: 1-18

4. Son VM, Chang CC, Wu MC, Guu YK, Chiu CH, et al. (2009) Dietary administration of the probiotic, Lactobacillus plantarum, enhanced the growth, innate immune responses, and disease resistance of the grouper Epinephelus coioides. Fish Shellfish Immunol 26: 691-698.

5. Sun YZ, Yang HL, Ma RL, Lin WY (2010) Probiotic applications of two dominan gut Bacillus strains with antagonistic activity improved the growth performance and immune responses of grouper Epinephelus coioides. Fish Shellfish Immunol 29: 803-809.

6. Bates JM, Mittge E, Kuhlman J, Baden KN, Cheesman SE, et al. (2006) Distinct signals from the microbiota promote different aspects of zebrafish gut differentiation. Dev Biol 297: 374-386.

7. Picchietti S, Mazzini M, Taddei AR, Renna R, Fausto AM, et al. (2007). Fish Shellfish Immunol 22: 57-67.

8. Birkbeck TH, Ringø E (2005) Pathogenesis and the gastrointestinal tract of growing fish. In: Microbial Ecology in Growing Animals. Edited by Holzapfel W and Naughton P. Biology of Growing Animals series. Edited by Pierzynowski SG and Zabielski R. Elsevier: Edinburgh 208-234.

9. Ringø E, Myklebust R, Mayhew TM, Olsen RE (2007) Bacterial translocation and pathogenesis in the digestive tract of larvae and fry. Aquaculture 268: 251 264

10. Zhou Z, Liu Y, Shi P, He S, Yao B, et al. (2009) Molecular characterization of the autochthonous microbiota in the gastrointestinal tract of adult yellow grouper (Epinephelus awoara) cultured in cages. Aquaculture 286: 184-189.

11. Romero J, Navarrete P (2006) 16S rDNA-based analysis of dominant bacterial populations associated with early life stages of coho salmon (Oncorhynchus kisutch). Microb Ecol 51: 422-430.

12. Kim DH, Brunt J, Austin B (2007) Microbial diversity of intestinal contents and mucus in rainbow trout (Oncorhynchus mykiss). J Appl Microbiol 102: 1654-1664

13. Navarrete P, Espejo RT, Romero J (2009) Molecular analysis of microbiota along the digestive tract of juvenile Atlantic salmon (Salmo salar L.) Microb Ecol 57: 550-561.

14. Tapia-Paniagua ST, Chabrillón M, Díaz-Rosales P, de la Banda IG, Lobo C et al. (2010) Intestinal microbiota diversity of the flat fish Solea senegalensis (Kaup, 1858) following probiotic administration. Microb Ecol 60: 310-319. 
Citation: Yang HL, Sun YZ, Ma RL, Li JS, Huang KP (2011) Probiotic Psychrobacter sp. improved the autochthonous microbial diversity along the gastrointestinal tract of grouper Epinephelus coioides. J Aquac Res Development S1:001. doi:10.4172/2155-9546.S1-001

15. He S, Zhou Z, Meng K, Zhao H, Yao B, et al. (2011) Effects of dietary antibiotic growth promoter and Saccharomyces cerevisiae fermentation product on production, intestinal bacterial community and non-specific immunity of hybrid tilapia (Oreochromis niloticus $Q \times 0$. aureus ${ }^{\lambda}$ ). J Anim Sci 89: 84-92.

16. Sun YZ, Yang HL, Ling ZC, Chang JB, Ye JD (2009) Gut microbiota of fast and slow growing grouper Epinephelus coioides. Afr J Microbiol Res 3: 713-720.

17. Sun YZ, Yang HL, Ma RL, Zhang CX, Lin WY (2011) Effect of dietary administration of Psychrobacter sp. on the growth, feed utilization, digestive enzymes and immune responses of grouper Epinephelus coioides. Aquacult Nutr 17: e733-e740.

18. Hovda MB, Lunestad BT, Fontanillas R, Rosnes JT (2007) Molecular characterisation of the intestinal microbiota of farmed Atlantic salmon (Salmo salar L.). Aquaculture 272: 581-588.

19. Buddington RK, Krogdahl A, Bakke-McKellep AM (1997) The intestines of carnivorous fish: structure and functions and the relations with diet. Acta Physiol Scand Suppl 161: 67-80.

20. Ringø E, Sperstad S, Myklebust R, Refstie S, KrogdahlA(2006) Characterisation of the microbiota associated with intestine of Atlantic cod (Gadus morhua L.) The effect of fish meal, standard soybean meal and a bioprocessed soybean meal. Aquaculture 261: 829-841.

21. He S, Zhou Z, Liu Y, Shi P, Yao B, et al. (2009) Effects of dietary Saccharomyces cerevisiae fermentation product (DVAQUA®) on growth performance, intestinal autochthonous bacterial community and non-specific immunity of hybrid tilapia (Oreochromis niloticus $9 \times 0$. aureus ${ }^{\lambda}$ ) cultured in cages. Aquaculture 294: 99-107.

22. Sun YZ, Yang HL, Ma RL, Song K, Lin WY (2011). Molecular analysis of autochthonous microbiota along the digestive tract of juvenile grouper Epinephelus coioides following probiotic Bacillus pumilus administration. J Appl Microbiol 110: 1093-1103.

23. Lane DJ (1991) 16S/23S rRNA sequencing. In: Nucleic Acid Techniques in Bacterial Systematic. Edited by Stackebrandt E and Goodfellow MD. John Wiley and Sons: New York 115-175.

24. Konstantinov SR, Zhu WY, Williams BA, Tamminga S, de Vos WM, et al. (2003) Effect of fermentable carbohydrates on piglet faecal bacterial communities as revealed by denaturing gradient gel electrophoresis analysis of $16 \mathrm{~S}$ ribosomal DNA. FEMS Microbiol Ecol 43: 225-235.

25. Maidak BL, Cole JR, Parker CT Jr, Garrity GM, Larsen N, et al. (1999) A new version of the RDP (Ribosomal Database Project). Nucleic Acids Res 27: 171-173.

26. Ferguson RMW, Merrifield DL, Harper GM, Rawling MD, Mustafa S, et al (2010) The effect of Pediococcus acidilactici on the gut microbiota and immune status of on-growing red tilapia (Oreochromis niloticus). J Appl Microbiol 109 851-862.

27. Sugita H, Hirose Y, Matsuo N, Deguchi Y (1998) Production of the antibacteria substance by Bacillus sp. strain NM 12, an intestinal bacterium of Japanese coastal fish. Aquaculture 165: 269-280.

28. Abd El-Rhman AM, Khattab YAE, Shalaby AME (2009) Micrococcus luteus and Pseudomonas species as probiotics for promoting the growth performance and health of Nile tilapia, Oreochromis niloticus. Fish Shellfish Immunol 27: 175-180.

29. Liu CL, Shao ZZ (2005) Alcanivorax dieselolei sp. nov., a novel alkanedegrading bacterium isolated from sea water and deep-sea sediment. Int J Syst Evol Microbiol 55: 1181-1186.

30. Nakano M, Okunishi S, Tanaka R, Maeda H (2009) Denitrifying activity and homologous enzyme analysis of Alcanivorax dieselolei strain N1203. Biocontro Sci 14: 97-105

31. Kuroda M, Yamashita A, Hirakawa H, Kumano M, Morikawa K, et al. (2005) Whole genome sequence of Staphylococcus saprophyticus reveals the pathogenesis of uncomplicated urinary tract infection. Proc Natl Acad Sci USA 102: $13272-13277$.

32. Shah KL, Tyagi BC (1986) An eye disease in silver carp, Hypophthalmichthys molitrix, held in tropical ponds, associated with the bacterium Staphylococcus aureus. Aquaculture 55: 1-4.

33. Gil P, Vivas J, Gallardo CS, Rodríguez LA (2000) First isolation of Staphylococcus warneri, from diseased rainbow trout, Oncorhynchus mykiss (Walbaum), in Northwest Spain. J Fish Dis 23: 295-298.

34. Ringø E, Bendiksen HR, Wesmajervi MS, Olsen RE, Jansen PA, et al. (2000) Lactic acid bacteria associated with the digestive tract of Atlantic Salmom (Salmo salar L.). J Appl Microbiol 89: 317-322.

35. Merrifield DL, Burnard D, Bradley G, Davies SJ, Baker RTM (2009) Microbia community diversity associated with the intestinal mucosa of farmed rainbow trout (Oncorhynchus mykiss Walbaum). Aquacult Res 40: 1064-1072.

36. Yang HL, Sun YZ, Ma RL, Ye JD (2011) PCR-DGGE analysis of the autochthonous gut microbiota of grouper Epinephelus coioides following probiotic Bacillus clausii administration. Aquacult Res.
This article was originally published in a special issue, Probiotic \& Prebiotic Applications in Aquaculture handled by Editor(s). Dr. Daniel L. Merrifield, University of Plymouth, UK; Prof. Zhigang Zhou, Chinese Academy of Agricultural Sciences, China 